\title{
A New Record for Mangrove Plume Moth Cenoloba obliteralis (Walker, 1864) (Fam. Tineodidae : Lepidoptera ) Attacking Mangrove Plant in Saudi Arabia Abu El-Ghiet, U. M. \\ Plant Protection Dept., Desert Res. Center, Mataria, Cairo, Egypt.
}

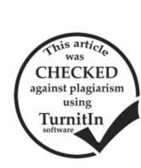

\section{ABSTRACT}

The first record for Mangrove plume moth Cenoloba obliteralis (Walker) on infested fruit of mangrove Jazan Red Sea coasts, Saudi in March 2016. The larvae of mangrove plume moth C. obliteralis feeding on flowering buds and consumed the cotyledons of fruits. During this study, six sites of mangrove plant were screened for infestation by C. obliteralis through four seasons. We observed that, the flower buds were available at different seasons meanwhile fruits were available in spring and autumn. Female of C. obliteralis was laid eggs at the base of the flower buds as a separate egg, after egg hatching larvae feed on flowers before its open and navigate between the cluster flowers. The infected flowers were diagnostic by presence of larvae feces and holes which made by the larvae. The direct examination of fruits, showing that female was laid eggs on the location of fruits communication per plant. After egg hatching new emergence larvae was enter into fruits and it feeds on the content of cotyledons. The mature larva was exit from the weakest site in the cortex of the fruit (attaching site of both cotyledons). No more than a larva watched inside the fruit as well as no cocoon seen inside the fruit .

Keywords: Mangrove, Cenoloba obliteralis, Jazan, new record

\section{INTRODUCTION}

Unusually the Family Tineodidae in several cases modified the wings like in some related moths; wings in some this family are transform to several rigid spines (ToL 2003). This family, are small when compared with 20 species as a global total described to date; some species undescribed are suspected or known to exist however. Clarke 1986, mentioned that, they seems to be of Australian origin, where they are most diverse, but range through the Wallacea to South Asia and Southeast, and into Pacific Ocean to Islands of Marquesas. Two mangrove species are recorded along the Saudi Red Sea coasts namely Avicennia marina and Rizophora mucronata. Mangrove forests comprise or trees and shrubs; welldeveloped forests are seen in the sheltered shores of the intertidal zones of tropical and subtropical oceans and seas of the world, particularly those protected from wave action.

The Red Sea mangal is special interest, found on substrates of relatively thin sediment over subfossil or raised coral rock and typically occurs in regions of high salinity, low oxygen and limited fresh water in flow (Kassas and Zahran 1967 and Zahran, 1977). The Mangrove plant in forests and wetlands usually considered to be of great conservatory value in urban areas (Hamilton and Snedaker, 1984; McGuinness, 1988 and Morris, 1995). Planting and Nursery techniques developed for species of major, while the additional species still under investigation. Outbreaks of insect pest species have been expected as a result of extensive monospecific plantations, in addition, other problems also encountered but in wood production, coastal protection stabilization and land reclamation, the afforestation of large-scale for mangrove appears beneficial in both technically possible and socioeconomically (Saenger and Siddiqi, 1993). Most mangrove forests are spread in the Kingdom of Saudi Arabia on the Red Sea coast, and there are few of them on the Arabian Gulf coast and occupy about $204 \mathrm{~km}^{2}$ area of the Kingdom (Ormond et al. 1988 and NCWD 1990). Beside many beneficial insects, pollinator and natural enemies, associated with mangrove forests, there are many harmful insects (pests) attacking it. The later can cause damage to mangrove swamps being herbivores, borers, seed pests and forgivers. Herbivores insects can cause death of mangrove seedlings and remove leave area from some species of mangrove trees up to $35 \%$, also the insects attack by borings and damage a large proportion of mangrove seeds (Robertson and Lake 1991). The wood borers insects attack and damage live trees, which can widespread in the most forests (Schowalter 2000). Diversity and seasonality of Insect species associated with mangrove plants grown at different sites of Red sea, Egypt was done by (Abu ElGhiet, 2006) during its study, the examination of A. marina fruits two of larvae species namely; Ectomyelois ceratoniae (Fam. Pyralidae) and the common herbivores, mangrove plume moth C. obliteralis (Fam. Tineodidae) on A. marina fruits in forests of mangrove in Red Sea, Egypt. The two insect species were recorded for the 1 st time on the mangrove fruits in Egypt during this study. C. obliteralis that respond to the yellow color, so, traps yellow sticky are efficient to population densities monitor of day-flying insects; we can also be used in control measure in large placing and high number of traps inside the field. Abu ElGhiet (2011) used yellow sticky traps for monitoring of mangrove plume moth $\mathrm{C}$. obliteralis, It was also hanged inside the field of mangrove trees, starting from 16th of April 2007 to the end of March 2009 and examined twice monthly and the role of Trichogramma spp. in reduction the rate of infestation by the mangrove plume moth $C$. obliteralis were studied. This was found to be very effective in controls the pest.

In KSA there have been no comprehensive surveys of mangrove insects, though some brief surveys have been conducted, the main aim of this work is to document recent records obtained from examining and identified.

\section{MATERIALS AND METHODS}

C. obliteralis sampling was performed at six stations around the coastal regions of Jazan from January 2016 to December 2016 (Table 1).

1-Description of study sites:

As show in Table 1 and Fig. 1 the study location was described 
Table 1. Latitude and longitude of the sampling stations

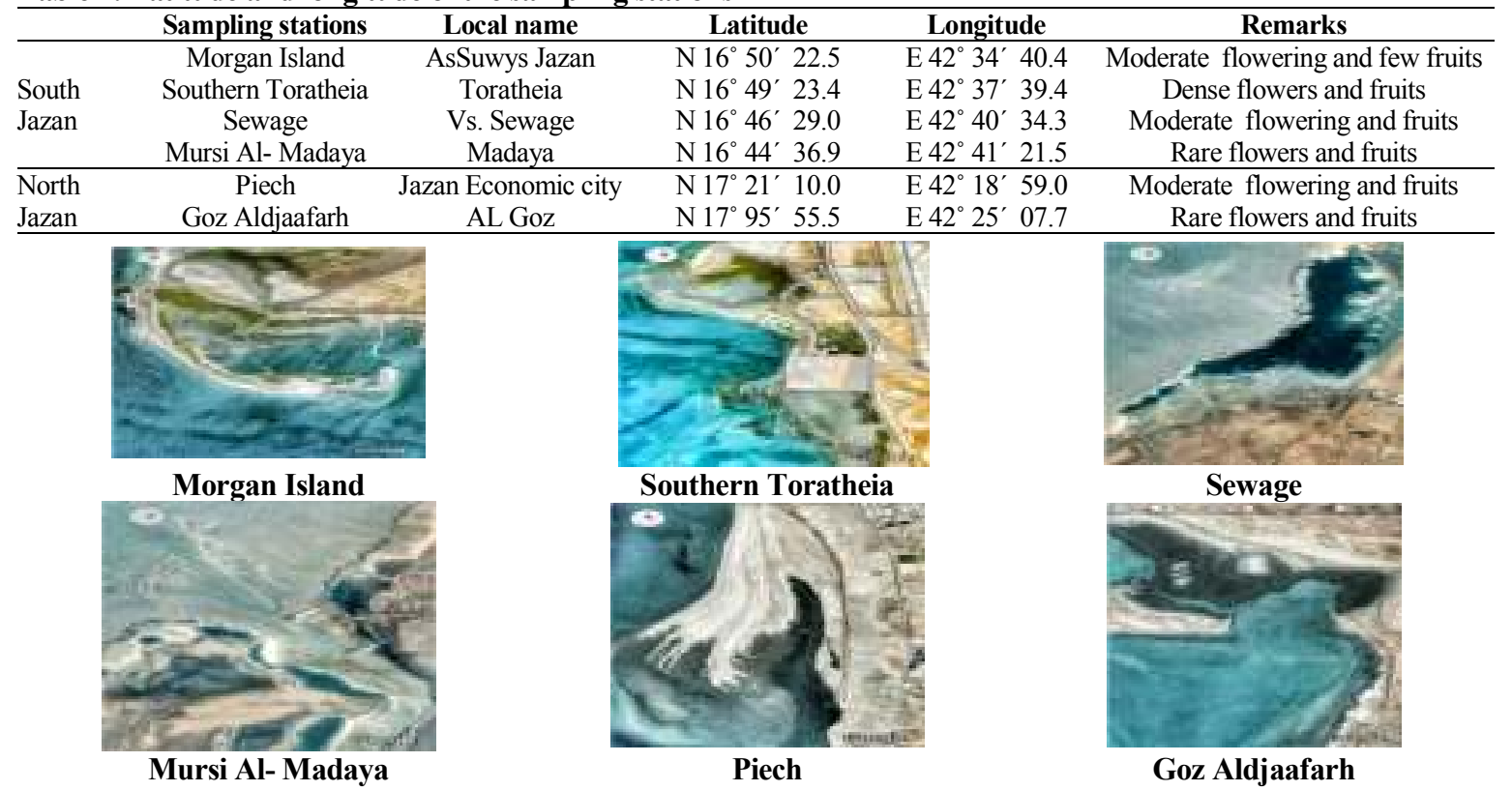

\section{2- Fruits sampling}

Fig. 1. The six study sites were taken from the Google satellite maps.

Mangrove (Avicennia marina) bunches fruit were collected during the fruiting season. In vacation site, the fruit bunchs were collected from each site with sampling unit of about 200 fruits in five replicates, 40 fruits for each (Abu El-Ghiet 2006).

\section{3-Insect collection and identification:}

Insect larvae Collected from the fruits were incubated until adult emergence and identified using different taxonomic keys and confirmation was done with the help of experts. All the specimens collected are preserved in the Insect Specimen Room of Biology Department, Faculty of science, Jazan University, K. S. A.

\section{RESULTS AND DISCUSSION}

\section{Results}

During the present study, examination of A. marina fruits revealed the larvae of mangrove plume moth $C$.

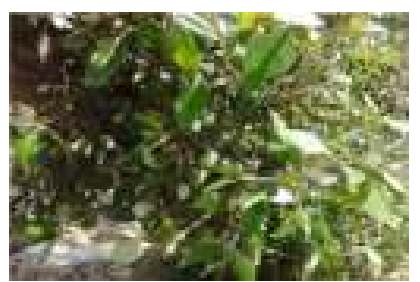

A

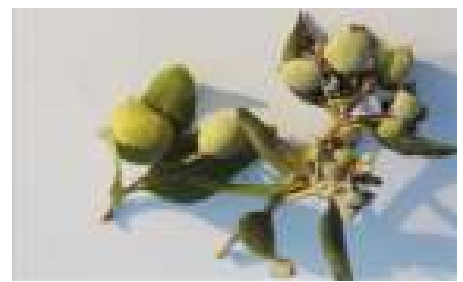

B obliteralis (Fam. Tineodidae) as common herbivores on $A$. marina fruits in forests of mangrove in Jazan, KSA. These insect species was recorded for the 1st time on the mangrove fruits in KSA.

The fruit of $A$. marina is roughly spherical to ovoid (about $3 \mathrm{~cm}$ ), a pair of cotyledons with one rounded side and one flattened side. The embryo comprises an embryonic axis (radicale, hypocotyls, epicotyls and plumule) and two large, fleshy cotyledons that contribute the bulk of the propagule. The cotyledons are tightly packed and flooded in half, the inner one stacked inside the outer one. The new branches of plant contain fruits of different sizes and different stages of growth (Fig. 2 A\&B).

Fruits were examined externally to find out pest exit holes and internally to determine the damage caused to the cotyledon. Accordingly, the inspected fruits were segregated in to healthy and infested ones.

Fig. 2 A \& B. Fruit of $A$. marina A- full-grown fruit from Piech location, B- deferent stages development fruits from Southern Toratheia location.

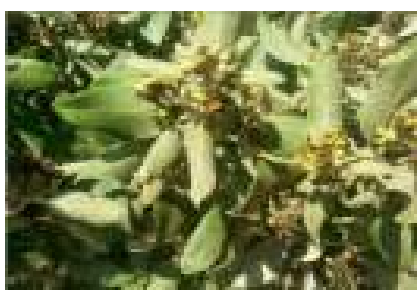

A

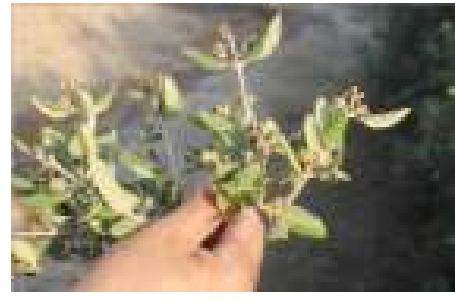

B

Fig. 3 A \& B. Two types of flower buds of $A$. marina in different development stages and different location A- from Goz Aldjaafarh location, B- Morgan Island 
During this study, six sites of mangrove plant screened for infestation by $C$. obliteralis through four seasons. We observed that, the flower buds were available at different seasons meanwhile fruits were available in spring and autumn. The fruits were formation was high in the sites of Piech, Morgan Island and Southern Toratheia in end of February till the beginning of April.

Female $C$. obliteralis was laid eggs at the base of the flower buds as separate, after hatching larvae feed on flowers before it is open and navigate between the cluster flowers. The infected flowers were diagnosted by presence of larvae feces and holes which made by the larvae.

The direct examination of fruits showed that female was laid eggs on the location of fruits communicated per plant. After egg hatching newly emerging larvae entered into fruits and it feeds on the content of cotyledons. The mature larva was exit from the weakest site in the cortex of the fruit (attaching site of both cotyledons). No more than one larva watched inside the
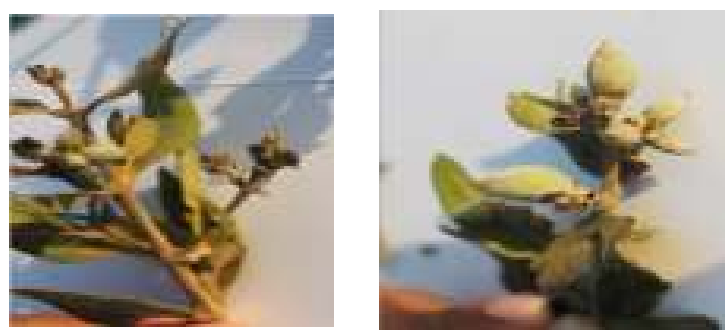

A fruit and no cocoon seen inside the fruit. There is a note from the total number of fruits studied, nearly $10 \%$ of the fruit examined, larvae were found inside fruit and the remaining infected without larvae.

Larval presence was observed maximum in the medium sized fruits (Fig. 2B) whereas it was much reduced in the smallest and full growing fruits.

The history of life for the mangrove plume moth $C$. obliteralis is not described briefly before. Female lays her eggs outside the flower cluster or on surface of fruit. After hatching, the larva burrows into the stalk of the flower cluster or directly into the fruit (Fig. 4A). The larva develops by feeding on the floral buds and developing cotyledon, creating irregular galleries in the cotyledon (Fig. 4B). The mature larvae leave these galleries and pupate in a white, silky cocoon either within or outside the fruit. Consequently, the larva might generate an exit hole in the surface of the cotyledon and the pericarp.
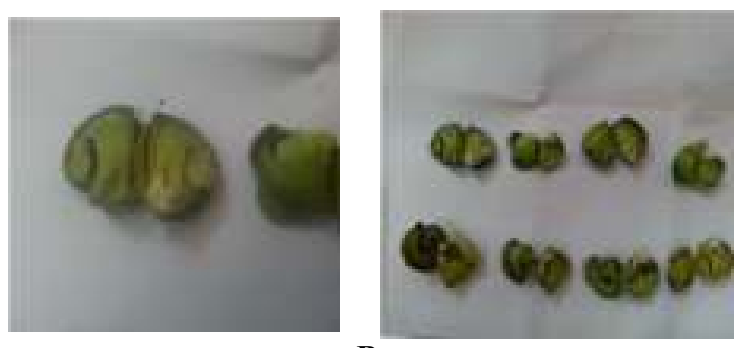

B

Fig. 4 A \& B. Types of flower buds and fruits of $A$. marina infested by $C$. obliteralis. A- Infested floral buds, Binfested fruits.

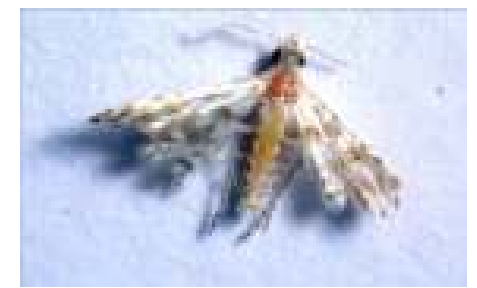

$\mathbf{A}$

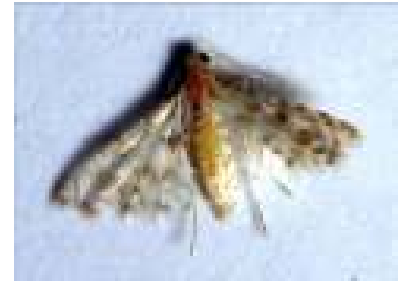

B

Fig. 5A\&B. Adult stage of $C$. obliteralis.

\section{Discussion}

The mangrove plume moth, $C$. obliteralis (Fam. Tineodidae) is found to be common pest on A. marina fruits in mangrove forests which agree with Minchinton and Dalby (2001). This insect was recorded earlier by Abu El-Ghiet (2006) on the Egyptian Red Sea mangroves.

Burrows (2003) tabulated the literature for folivorous insect from mangrove in Australia and commented that, $C$. obliteralis consider to be a fruit-feeder (Hutchings and Saenger 1987 and Hockey and Debar 1991) but west West and Thorogood (1983) reported $C$. obliteralis as defoliating of A. marina. Accord to Hutching and Recher (1974) it is feeding on fruit and young shoots of A. marina. Tropic interactions involving plants and animals in tropical mangrove forests have important role in controlling in fluencies on several population, community and ecosystem level processes, where insect herbivores remove up to $35 \%$ of leaf area from some mangrove species and can cause the death of seedlings (Robertson and Lake 1991).
Research in scientific papers, references and communication with specialists entomology taxonomist in different universities of the Kingdom I did not see one of the researchers conducted a detailed study on insects associated with mangrove and I did not find a researcher to do studies on the insect under study, Cenoloba obliteralis not been registered before in the Kingdom of Saudi Arabia

This is very consistent with what we did during the study and confirmed by the pictures of the collected samples, adult insects and larvae collected from the fruits.

According to Abu El-Ghiet (2006 \&2011).This insect was recorded on the west coast of the Red Sea in different regions where the $A$. marina plant growing and also monitored on flowers and fruits of different sizes. The result of our study was consistent with that and the adult insect corresponds to the shape and traits.

Reference samples were saved in the Biology Department at the Faculty of Science, Jazan University.

Samples will be sent to King Saud University in Riyadh and King Abdulaziz University in Jeddah to be 
reserved as reference references for species in the classification research departments.

\section{ACKNOWLEDGMENTS}

Author would like to Prof. Dr. Salah Abbutalb and Dr. Maqbool Thaikkottathil (Faculty of Science, Jazan University) for the help and for accompanying us in some field trips. I would also like to thank my friend Maeed AlQahtani from the local people for traveling with me on my trips and my visits to all study sites.

\section{REFERENCES}

Abu El-Ghiet, U. M. H. (2006) Ecological studies on insects associated with mangrove plant naturally growing on the Red Sea Coast, Egypt. M. Sc. Thesis, Fac. of Science, AL-Azhar Univ., Cairo, Egypt.

Abu El-Ghiet, U. M. H. (2011) Studies on certain insect pests attacking mangrove plants and their management. Ph. D. Thesis, Fac. of Science, ALAzhar Univ., Cairo, Egypt.

Burrows, D. W. (2003). The role of insect leaf herbivory on the mangroves Avicennia marina andRhizophora stylosa. Ph.D. thesis, James Cook University, 238 p.

Clarke, J F (1986): Pyralidae and Microlepidoptera of the Marquesas Archipelago. Smithsonian Contributions to Zoology 416: 1-485.

Hamilton, L. S. and Snedaker, S. C. (1984): Handbook for mangrove area management. UNEP/East-West Centre, Environmental Policy Institute, Hawaii.

Hatchings, P. and Saenger, P. (1987): Ecology of mangrove. University of Queensland press. St. Lucia, Brisbane.

Hockey, M. J. and de Baar, M. (1991): Some records of moths (Lepidoptera) from mangrove in southern Queensland, Australian Entomologist Magazine 18: 57- 60.

Hutching, P. A. and Recher, H. F. (1974): The fauna of Careel Bay with commonts on the ecology of mangrove and sea-grass communities. Australian Zoologist 18:99-128.

Kassas , M. and Zahran, M. A. ( 1967 ): On the ecology of the red sea littoral salt marsh, Egypt . Ecol. Monogr. $37: 279-315$.
McGuinness, K. A. (1988): The Ecology of Botany Bay and the Effects of Man's Activities: a Critical Synthesis. Institute of Marine Ecology, University of Sydney.

Minchinton, T. E. and Dalby, B. M. (2001): Frugivory by insect on mangrove on the early life history of Avicennia marina. Oecologia, 129: 243-252.

Morris, P. (1995): Ecology-overview. In: Morris, P., Therivel, R. (Eds.), Methods of Environmental Impact Assessment. Page Bros., England, pp. 197226.

National Commission for Wildlife Conservation and Development (NCWCD), 1990. A system plan for protected areas for wild life conservation and sustainable rural development in Saudi Arabia . NCWCD/IUCN, Riyadh.

Ormond, R. F. G., Price, A. R. G .and Dawson-shepherd, A. R., 1988. The distribution and character of mangrove in the Red Sea, Arabian Gulf and Southern Arabia . Proceedings of the UNDP/UNESCO Regional Mangrove Project, Colombo, 11-14 Nov. 986 , pp.125-130.

Robertson, A. I. and Lake, P. S. (1991): Plant-animal interactions and the structure and function of mangrove forest ecosystems. Ecological interactions. Proceedings of a symposium of the Ecological Society of Australia, held at University of Melbourne, 25-28 September 1990. Australian Journal of Ecology, 16 (4): 433-443.

Saenger P. and Siddiqi N. A. (1993): Land from the sea: The mangrove afforestation program of Bangladesh. Ocean \& Coastal Management Vol. 20 (1): 23-39.

Schowalter,T .D. (2000): .Insects as regulaors of ecosystem development. In Coleman, DC and Hendrix, PF (eds), Invertbrates as webmasters in ecosystems. CABI Publishing, pp.99-114.

ToL (2003): Tree of Life Web Project, Alucitoidea. Version of 2003-JAN-01. Retrieved 2011-SEP-24.

West, R. J. and Thorogood, C. A. (1983): Environmental stress causing mangrove dies back in NSW. Australian fisheries 42. (8): 16-20.

Zahran,M. A. (1977): Wet formation of the African Red Sea coast, in wet coastal ecosystem . Chapman, V.J.(ed), Elsesvier Amsterdam ,pp.215-231.

\section{Cenoloba obliteralis (Walker, 1864) تسجيل جديد في المملكة العربية السعودية لحشرةعثة ثمار الماتجروف (Fam. Tineodidae: Lepidoptera)

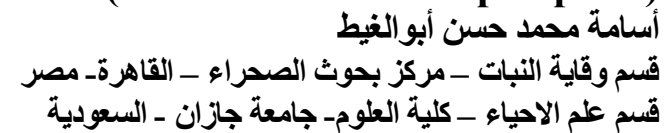

يقدم هذا البحث توثيقا عن التسجيل الأول لحشرة فراشة ثمار المانجروف التي تصيب نبات الثوري وذللك في مارس 2016 بمنطقة

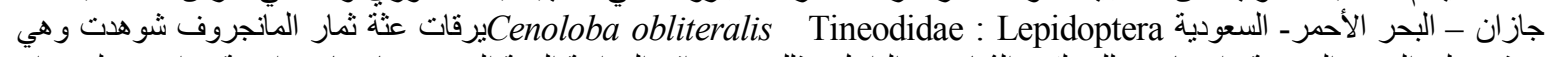

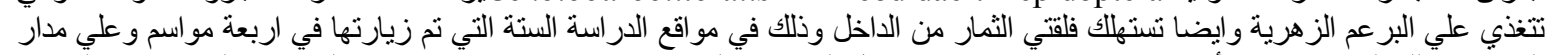

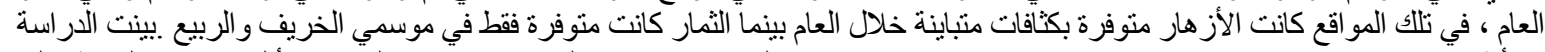

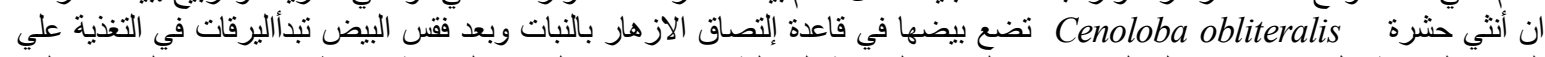

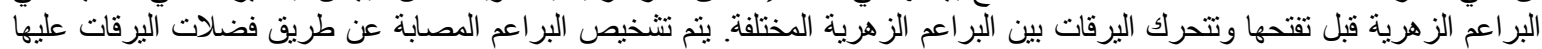

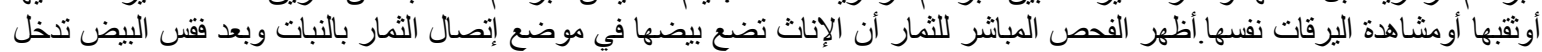

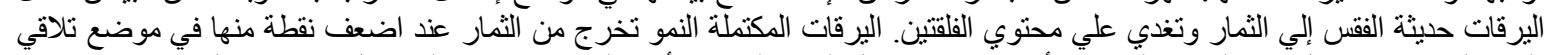

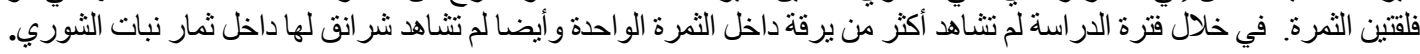

